\title{
Surface Ozone Concentration in Russia in the Second Half of 2020
}

\author{
V. V. Andreev ${ }^{a, *}$, M. Yu. Arshinov ${ }^{b}$, B. D. Belan ${ }^{b}$, S. B. Belan ${ }^{b}$, D. K. Davydov ${ }^{b}$, V. I. Demin ${ }^{c}$, \\ N. F. Elansky ${ }^{d}$, G. S. Zhamsueva ${ }^{e}$, A. S. Zayakhanov ${ }^{e}$, G. A. Ivlev ${ }^{b}$, A. V. Kozlov ${ }^{b}$, S. N. Kotel'nikov , $^{\prime}$ \\ I. N. Kuznetsova ${ }^{g}$, V. A. Lapchenko ${ }^{h}$, E. A. Lezina ${ }^{i}$, O. V. Postylyakov ${ }^{d}$, D. E. Savkin ${ }^{b}$, I. A. Senik ${ }^{d}$, \\ E. V. Stepanov $f$, G. N. Tolmachev ${ }^{b}$, A. V. Fofonov ${ }^{b}$, I. V. Chelibanov', \\ V. P. Chelibanov ${ }^{j}$, V. V. Shirotov ${ }^{k}$, and K. A. Shukurov ${ }^{d}$ \\ ${ }^{a}$ Peoples' Friendship University of Russia, Moscow, 117198 Russia \\ ${ }^{b}$ V.E. Zuev Institute of Atmospheric Optics, Siberian Branch, Russian Academy of Sciences, Tomsk, 634055 Russia \\ ${ }^{c}$ Polar Geophysical Institute, Russian Academy of Sciences, Apatity, 184209 Russia \\ ${ }^{d}$ Obukhov Institute of Atmospheric Physics, Russian Academy of Sciences, Moscow, 119017 Russia \\ ${ }^{e}$ Institute of Physical Material Science, Siberian Branch, Russian Academy of Sciences, Ulan-Ude, 670047 Russia \\ ${ }^{f}$ Prokhorov General Physics Institute, Russian Academy of Sciences, Moscow, 119333 Russia \\ ${ }^{g}$ Hydrometeorological Center of Russia, Moscow, 123242 Russia \\ ${ }^{h}$ Vyazemsky Karadag Scientific Station - Nature Reserve of Russian Academy of Sciences, Kovalevsky Institute \\ of Biology of the Southern Seas, Russian Academy of Sciences, Feodosia, 298188 Russia \\ ${ }^{i}$ State Nature Organization Mosecomonitoring, Moscow, 119019 Russia \\ ${ }^{j}$ Instrument-Making Enterprise OPTEC, St. Petersburg, 199178 Russia \\ ${ }^{k}$ Typhoon Scientific and Production Association, Obninsk, Kaluga oblast, 249038 Russia \\ *e-mail: bbd@iao.ru
}

Received February 25, 2021; revised February 25, 2021; accepted March 5, 2021

\begin{abstract}
We present information on ozone concentration in the surface air layer in the second half of 2020. Data were obtained at 13 stations located in different regions of Russia. We estimated the excess over hygienic standards of the Russian Federation, both in the second half of the year and throughout 2020. It is shown that the daily average maximum permissible concentration of ozone is regularly exceeded at all stations. There are cases of exceeding the one-time maximum permissible concentration.
\end{abstract}

Keywords: atmosphere, air, concentration, ozone, maximum permissible concentration, surface layer DOI: $10.1134 / \mathrm{S} 1024856021040035$

\section{INTRODUCTION}

This paper continues a cycle of publications, aimed at informing the scientific community about ozone content in the surface air layer on the territory of Russia (addressing the second half of 2020). This information is important because ozone in the troposphere is extremely hazardous both for biological and environmental structures. At the same time, the governmental-level monitoring of ozone concentration is not organized. The population does not have such information and, hence, cannot adequately respond to ozone concentrations exceeding maximum permissible concentration (MPC). Medical practitioners know nothing about the specific ozone effect on individuals and have no methods for neutralizing this effect.

In the period of time considered in this review, we can single out two specific features. The first is associated with the coronavirus pandemic, fighting which has weakened the economic activities and, hence, anthro- pogenic emissions, with ensuing air cleansing in cities. The second feature is that 2020 had been the warmest on Earth throughout the observation period [1]. This is despite the development of an El Niño event, which has a cooling effect on the planet. However, the pandemic is considered by the scientific community to not eliminate, but just to postpone, the implementation of measures to mitigate the consequences of global warming on the environment [2-4].

As numerous studies showed, the lockdown, which weakened the economic activities of population, did reduce the air pollution level in a number of cities. Based on work [5], the $\mathrm{PM}_{2.5}, \mathrm{PM}_{10}, \mathrm{NO}_{2}$, and CO concentrations decreased by 41, 52, 51, and $28 \%$, respectively, in Delhi, Mumbai, Chennai, Calcutta, and Bangalore in March-April 2020. In central Europe, the $\mathrm{NO}, \mathrm{NO}_{2}$, and $\mathrm{CO}$ concentrations and the total number of particles with diameters $<100 \mathrm{~nm}$ decreased by $68,46,27$, and $28 \%$ in 2020 relative to the 
(2017-2019) average reference [6]. Based on data of work [7], the level of the main pollutants in the atmosphere decreased by $30-50 \%$ in Moscow in the period of restrictive measures.

At the same time, the ozone content increased despite reduced precursor gas concentrations. Ozone increase by $69.7 \%$ was noted in Shenyang (China) [8], by $42 \%$ in Great Britain [9], and by 14 to $27 \%$ in European cities [10]. This effect is quite justified considering the distortion of the balance in the $\mathrm{NO}-\mathrm{O}_{2}-\mathrm{NO}_{2}$ triad [11, 12].

Authors of work [13] hypothesized that ozone can influence the spread of coronavirus itself. Their regression analysis showed that the SARS-CoV-2 spread decreased as ozone concentration grew from 48 to $94 \mu \mathrm{g} / \mathrm{m}^{3}$ at the 0.04 significance level. Unfortunately, no other similar studies were found.

Of course, the level of ozone content in the atmosphere during 2020 was influenced not only by lockdown announced due to the coronavirus. There were also atmospheric processes in the course of which ozone could have been generated or destructed. This was addressed in work [14], which showed that, upon the lockdown announcement, the air pollution level decreased and the ozone generation rate increased, but not in every city.

Ozone concentration in the surface air layer may vary several-fold in the long-term behavior; therefore, the existing ozone trends should be accounted for in assessing lockdown consequences. The consortium of organizations arranged to prepare reviews does not yet have a long time series of surface ozone concentrations. Therefore, no independent task was formulated in this review to elucidate the lockdown consequences. Possibly, we will return to this issue in subsequent publications after the necessary number of measurements is accumulated.

\section{DESCRIPTION OF STATIONS AND INSTRUMENTS USED}

The total list of stations and their instrumentation, as well as a description of the operational mode and calibrations, were given in [15]. Here, we will describe the Apatity and Boyarsky stations, which remained beyond the scope of the previous review.

Ozone measurements in Apatity, Murmansk oblast, are carried out on the territory of Akademgorodok, most of which is a park zone. Coordinates of the site are $67^{\circ} 34^{\prime} 14^{\prime \prime} \mathrm{N}, 33^{\circ} 23^{\prime} 51^{\prime \prime} \mathrm{E}$, altitude $180 \mathrm{~m}$ above sea level. A UV ozonometer Dasibi 1008-AH is used as the measuring instrument. The measurements are carried out at one-minute time resolution. Air is collected at an altitude of $15 \mathrm{~m}$ above the Earth's surface. Data on the surface ozone concentration (SOC) in the region are complemented by series of measurements in the background regions, which are currently not regular. An electrochemical ozonometer is used for this. The description of the instrument and its metrological properties were presented in [16].

The Boyarsky monitoring station is located in the Republic of Buryatia, on the southeastern coast of the Lake Baikal. Its coordinates are $51^{\circ} 51^{\prime} 10^{\prime \prime} \mathrm{N}$, $106^{\circ} 02^{\prime} 28^{\prime \prime} \mathrm{E}$, and its altitude is $516 \mathrm{~m}$ above sea level. The region is characterized by large temperature contrasts between the lake and adjoining territory, which are enhanced due to closed position of Baikal, surrounded by mountain ridges in all directions. The temperature gradient between the lake hollow and adjoining dry depressions, reaching $20^{\circ} \mathrm{C}$ and larger, is one of the main factors of formation and development of intrahollow circulation and its propagation into the lake basin, often favoring accumulation of atmospheric pollutants. Boyarsk village can be considered to experience a weak anthropogenic effect. Certain effects can be exerted by small industrial centers: Babushkin $22 \mathrm{~km}$ away, Kamensk settlement $50 \mathrm{~km}$ away, and Selenginsk settlement $60 \mathrm{~km}$ away. A mixed forest (birch, pine, and cedar) lies in the immediate vicinity. There is a $30-\mathrm{m}$ mast at the station. To determine the concentration of surface ozone, air is collected at altitudes of 2 and $20 \mathrm{~m}$ above the Earth's surface via Teflon pipes. Measurements are carried out using a chemiluminescent gas analyzers $3.02 \mathrm{P}-\mathrm{A}$. The instrument is calibrated and zeroed automatically, using built-in ozone sources at the commands of the gas analyzers processors. Additionally, measurement error was episodically controlled by testing the gas analyzer with the use of a Mod. 8500 Monitor Labs calibrator. At the same altitudes, meteorological observations are also carried out with AMK-03 and EXMETEO acoustic meteorological complexes.

The coronavirus pandemic adversely impacted not only human health, but also many industrial processes and, in particular, the observations of the state of the environment, sometimes to a very significant degree [17]. Pandemic-associated restrictions had also an effect on ozone measurements in Russia. A few stations, mentioned in the previous review, had been closed, and some could only be operated in periods when restrictions were relaxed.

\section{MEASUREMENT RESULTS}

We begin our analysis with urban stations, located on densely populated territories (Fig. 1). All urban stations show a classical annual behavior of ozone, with concentration decreasing from summer toward winter.

In Moscow, there is a regional network of ecological monitoring at the State Nature Conservation Organization, Mosecomonitoring, which is specially authorized to carry out state ecological monitoring [18]. In this review, we present the data averaged over measurements at urban and roadside stations [19]. In the analysis, there are no data from suburban sites, or from the Losiny Ostrov nature reserve site. 

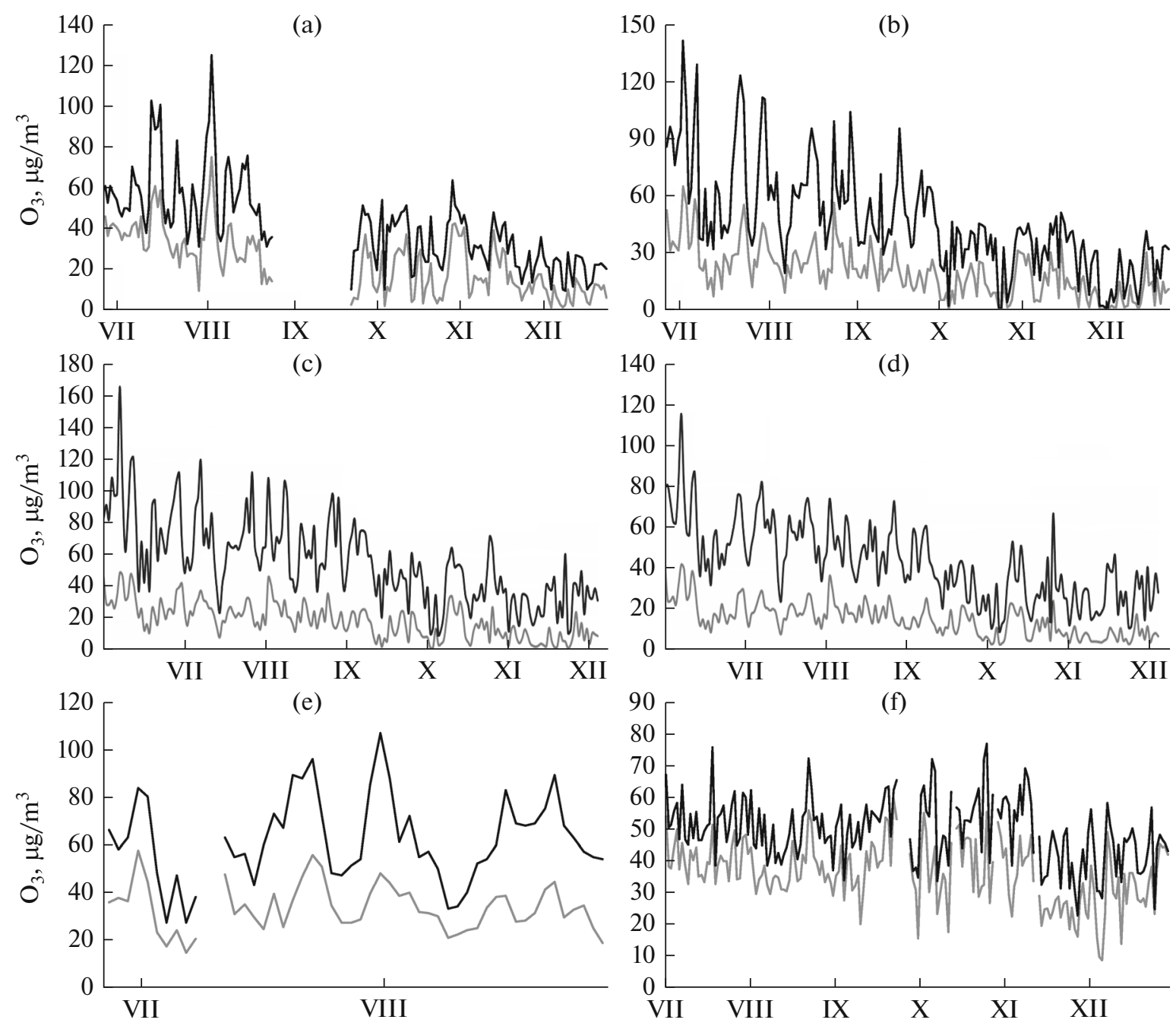

Fig. 1. Daily average (gray line) and daily maximal (black line) ozone concentrations in the surface air layer at stations: (a) OPTEC-P; (b) RUDN; (c) urban stations of Moscow; (d) roadside stations of Moscow; (e) Obninsk; and (f) Apatity.

Figures 1c and 1d show the area-averaged data from seven urban and five roadside stations. In the second half-year, there was a natural decrease in ozone content in the atmosphere and in the surface air; the seasonal ozone decrease ended with the formation of the annual SOC minimum in December. The monthly average SOC from July toward December decreased by the factors of 3-4: from 30 to $8 \mu \mathrm{g} / \mathrm{m}^{3}$ in residential regions, and from 23 to $7 \mu \mathrm{g} / \mathrm{m}^{3}$ on roadside territory. It is noteworthy that the monthly average SOC in August and September had been $5-10 \mu \mathrm{g} / \mathrm{m}^{3}$ smaller than annual average concentrations.

Owing to weather anomalies (predominant cloudy weather with frequent rainfalls), which prevented active photochemical ozone generation, the summer maximum of surface ozone, occurring most often in JulyAugust, was barely formed. As was indicated in [15], the main annual (April) SOC maximum has also been very weak, primarily because of the anomalously cold and rainy weather during spring in Moscow and, to a lesser degree, because of the sharp decrease in the emissions of pollutants to the atmosphere in the period of restrictive measures.

At Mosecomonitoring stations, the only ozone episode of the year was recorded on July 7. Ozone abruptly increased in the afternoon hours after the daily temperature increased to $+30^{\circ} \mathrm{C}$. SOC attained $167 \mu \mathrm{g} / \mathrm{m}^{3}$ at a single urban station (Maryinsky Park automatic air pollution monitoring station).

Characteristic features of SOC time behavior, recorded at RUDN monitoring station (Fig. 1b), located within the Third Ring Road in Moscow, nearly coincide with data obtained at Mosecomonitoring stations (Figs. 1c, 1d). There are only minor differences in the spans of the peaks in the amplitudes of the daily maximal SOC values, which can be explained by the specific positions of the stations and local features. 

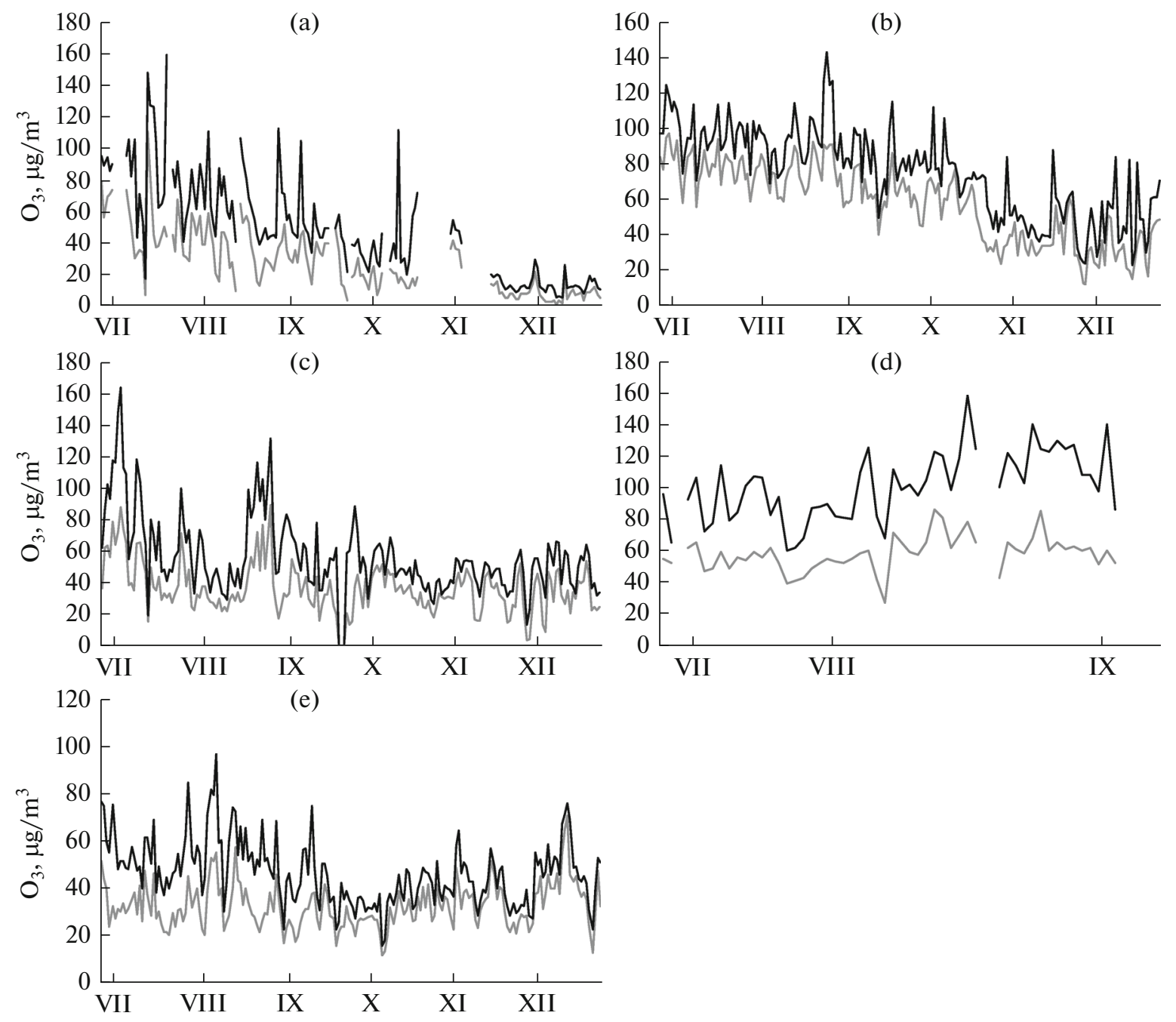

Fig. 2. Daily average (gray line) and daily maximal (black line) ozone concentrations in the surface air layer at stations: (a) OPTEC-PR; (b) SBEM Karadag; (c) Vyatskiye Polyany; (d) Boyarsky; and (e) Fonovaya.

In small cities, Obninsk and Apatity, the ozone concentrations were markedly lower (Figs. 1e, 1f) than in megalopolises, i.e., in Moscow and St. Petersburg (Figs. 1a-1c). In the period of time considered here, SOC values in Apatity were very far from the maximum permissible one-time concentrations $\left(\mathrm{MPC}_{\mathrm{m} . \mathrm{o}}=160 \mu \mathrm{g} / \mathrm{m}^{3}\right)$. The largest SOC values were recorded on October 26 and were only $81 \mu \mathrm{g} / \mathrm{m}^{3}$. The average maximal SOCs of $53 \mu \mathrm{g} / \mathrm{m}^{3}$ were in July, when temperatures are the highest and the period with solar insolation is the longest (the polar day in the region lasts from May 29 to July 14); and they were $43 \mu \mathrm{g} / \mathrm{m}^{3}$ in December, i.e., in the period with minimal illumination and polar night (from December 15 to 27). These values are lower than long-term average concentrations, respectively, by 5 and $15 \mu \mathrm{g} / \mathrm{m}^{3}$. However, long-term measurements indicate that maximal SOC values in these periods, which strongly differ by meteorological characteristics and by the level of UV radi- ation, usually turn out to be almost the same. In particular, long-term average maximal SOC values in Apatity are $58 \mu \mathrm{g} / \mathrm{m}^{3}$ from July 1 to 14 (polar day) and $56 \mu \mathrm{g} / \mathrm{m}^{3}$ from December 12 to 27 (polar night).

Five stations refer to background ones: OPTEC-PR, station of background ecological monitoring (SBEM) Karadag, Vyatskiye Polyany, Boyarsky, and the Fonovaya Observatory. Measurements at these stations are presented in Fig. 2.

From the figure, it can be seen that time behavior of ozone concentration has its own specific features. For instance, Vyatskiye Polyany and Fonovaya (Figs. 2c and $2 \mathrm{e}$ ) record the minimal concentration in October and not in December, as would be logical. It is still difficult to understand how natural this fact is. Possibly, these are anomalies in just a single year.

Spring and summer maxima in May and August $2020\left(142\right.$ and $\left.143 \mu \mathrm{g} / \mathrm{m}^{3}\right)$ are noted in the seasonal 
behavior of SOC at SBEM Karadag. Minimal monthly average values were observed in November and December 2020 (37 and $31 \mu \mathrm{g} / \mathrm{m}^{3}$ ). The maximal hourly average SOC value was recorded on August 31 at 18:00 LT; it was $143 \mu \mathrm{g} / \mathrm{m}^{3}$ at an air temperature of $28.3^{\circ} \mathrm{C}$ and relative humidity of $44 \%$. Minimal hourly average SOC value in the second half of 2020 was noted on December 19; it was $7 \mu \mathrm{g} / \mathrm{m}^{3}$ at an air temperature of $4.0^{\circ} \mathrm{C}$ and relative humidity of $84 \%$. During this day there was small-droplet rainfall with $2.1 \mathrm{~mm}$ of precipitation. The analysis showed that in the summer period the SOC value was maximal under southeasterly and southerly winds. With respect to the position of SBEM Karadag, this was transport from the seaward.

The behavior of ozone concentrations at SBEM Karadag is mainly determined, especially in warm season, by meteorological parameters and, primarily, by temperature. An intense photochemical ozone generation is observed in the cases of a favorable combination of meteorological conditions and the relationship between $\mathrm{NO}_{x}\left(\mathrm{NO}+\mathrm{NO}_{2}\right)$ concentrations and volatile organic compounds (VOCs). Such conditions occur at Karadag for high solar irradiance in the hot time of the year. VOC concentrations, sufficient for ozone generation, seem to occur due to natural sources (enhanced emissions from plants at high temperature) and/or long-range transport [20].

Based on measurements at six (both urban and background) stations, i.e., Vyatskiye Polyany, Apatity, OPTEC-P, OPTEC-PR, Karadag, and Tropospheric Ozone Research (TOR) station, there were shortterm, but strong, increases in the concentrations of surface ozone on August 9-10, 15, and 21-22, 2020. Probably, this was due to episodic decreases of the total ozone content (ozone anomaly) in the Northern Hemisphere during that period [21], which led to increased UV radiation. Thus, SOC increased during secondary photochemical reactions with the participation of ozone precursors-pollutants of atmospheric air-for increased intensity of UV radiation.

In contrast to urban stations (see Fig. 1), background stations (Fig. 2) show stronger and more variable time dynamics of ozone concentration in the second half of 2020. This seems to be due to high concentrations of VOCs, released by plants in forest massifs surrounding the stations [22, 23].

We turn to the remaining suburban station, i.e., the TOR station in Tomsk. Theoretically, owing to its position, this station should show an intermediate pattern between urban and background conditions. Measurements at the TOR station are presented in Fig. 3.

Since the TOR station and Fonovaya Observatory are separated by small $(60 \mathrm{~km})$ distance, the time dynamics of ozone concentration at both stations are similar in character (Figs. 2e and 3). However, there are also some differences: a higher daily average and maximal concentrations at the suburban station. Evi-

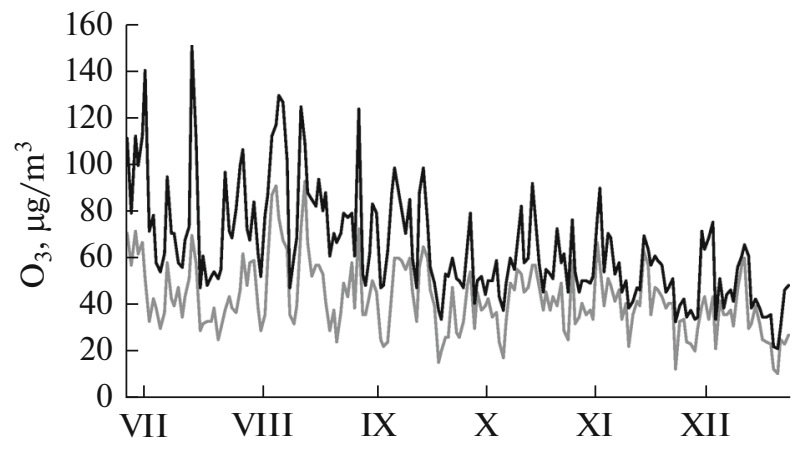

Fig. 3. Daily average (gray line) and daily maximal (black line) ozone concentrations in surface air layer at TOR station.

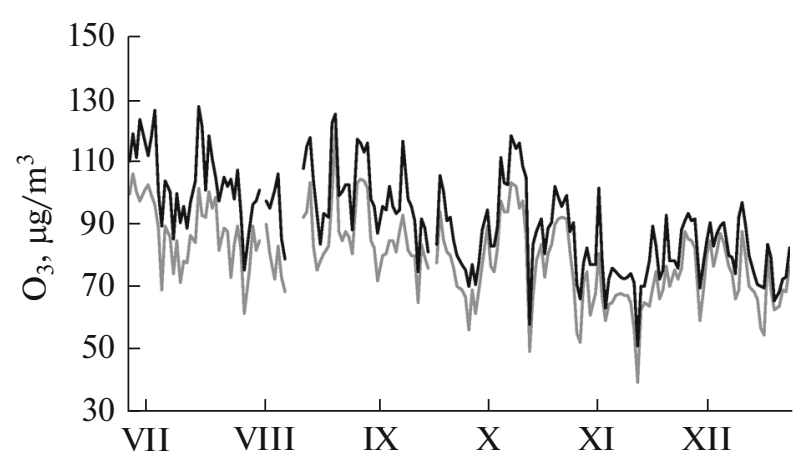

Fig. 4. Daily average (gray line) and daily maximal (black line) ozone concentrations in surface air layer at Kislovodsk station.

dently, the TOR station records higher concentrations because it is episodically in the plume of emissions from Tomsk, where there is an additional amount of ozone precursors.

The Kislovodsk high-mountain scientific station (KHMSS) occupies a special position (Fig. 4). Among all high-mountain stations, KHMSS stands out with a good topography and moderate climate, ensuring it is in free air most of the time.

In general traits, variations in surface ozone content at KHMSS in 2020 echoed those revealed in the previous observations: the seasonal behavior showed two local maxima (in spring and summer) and a minimum (in fall and winter) [24]. The annual absolute ozone maximum during 2020 was in March: from March 8 to 11 the hourly average values repeatedly exceeded $120 \mu \mathrm{g} / \mathrm{m}^{3}$ (see Fig. 4 [15]) and attained yearly maxima of $150 \mu \mathrm{g} / \mathrm{m}^{3}$. This was due to air transport from overlying layers, which was accompanied by an increase in the ozone concentration in the surface air layer, a decrease in air humidity, and wind strengthening. In addition to orographic effects, the long-range transport from southern direction cannot also be ruled out, will be considered below. In the period of the secondary sum- 


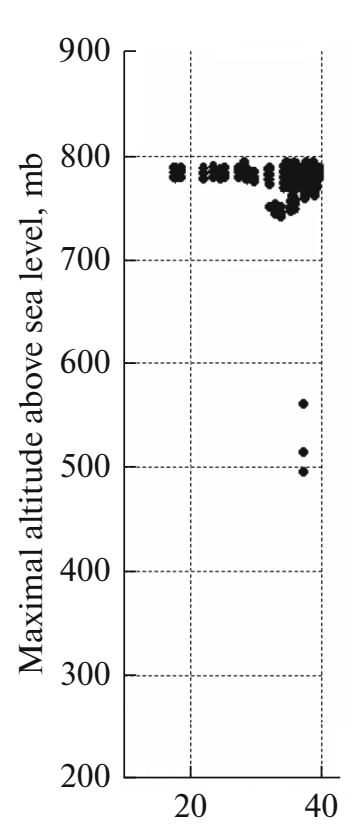

(a)

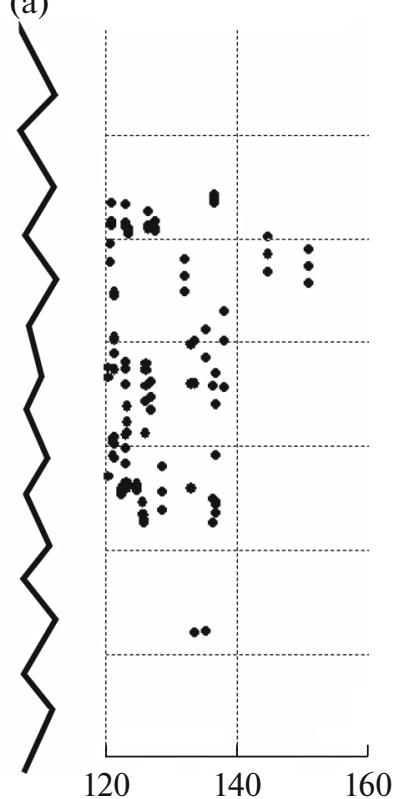

(b)

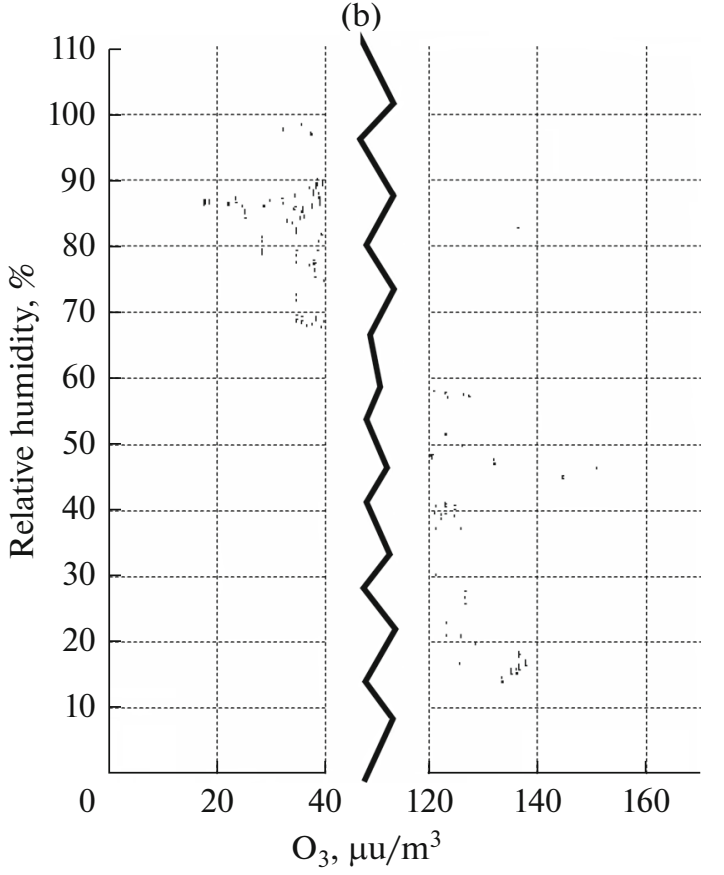

Fig. 5. KHMSS station: (a) maximal altitude of trajectory of an elementary air mass; and (b) relative air humidity for extreme surface ozone concentrations in 2020.

mer maximum, the level of $120 \mu \mathrm{g} / \mathrm{m}^{3}$ was exceeded on July 4, 8, and 20 and August 27.

The KHMSS-observed daily variations in the ozone content were much smaller than those from mainland stations: the amplitude of the daily variations even during summer does not exceed $10 \mu \mathrm{g} / \mathrm{m}^{3}$, with the minima in midday and with increased values at night (the surface atmosphere gains ozone due to transport from the direction of mountains, from the upper layers of the free troposphere, and, in particular, owing to the action of the mountain-valley circulation). In summer, a diurnal maximum was observed sometimes (possibly due to VOC and hay movers on days of hay making on meadows).

The trajectory analysis of air masses that arrived at KHMSS was carried out in order to consider the contribution of long-range transport to the observed extreme values of surface ozone. The trajectories were calculated using trajectory and dispersion model NOAA HYSPLIT_4 (HYbrid Single-Particle Lagrangian Integrated Trajectory) $[25,26]$ and global reanalysis archive of meteorological data NCEP/NCAR Reanalysis [27, 28]. Trajectories ended in the surface air layer $100 \mathrm{~m}$ thick above KHMSS. A total of 24000 back trajectories were modeled for all times of measurements of surface ozone in 2020 at KHMSS.

The back trajectory analysis shows that high hourly average concentrations $\left(>120 \mu \mathrm{g} / \mathrm{m}^{3}\right)$ are associated with the arrival of ozone-rich air of the free troposphere from altitudes up to $400 \mathrm{mb}$ (Fig. 5a). At the same time, the average trajectory altitude was $600 \mathrm{mb}$. These cases are characterized by low air humidity, up to $15 \%$.

Low hourly average ozone concentrations $\left(<40 \mu \mathrm{g} / \mathrm{m}^{3}\right)$ at KHMSS were recorded under high relative humidity $(>70 \%$, Fig. $5 \mathrm{~b})$ and were concurrent with its local cause, i.e., fogs (low, surface clouds). The trajectory analysis also showed that air in that case came from the valley: the maximal altitude of the corresponding trajectories in 2020 was $750-800 \mathrm{mb}$ (Fig. 5a), and the average altitude of the trajectories was $800-1000 \mathrm{mb}$. Low values of surface ozone under the conditions of high humidity in dense fog (usually more than $85 \%$ ) do not characterize the regional ozone field because a cloud is a local "regulator" of ozone concentration.

All the calculated trajectory array was processed to select two sets of trajectories, corresponding to extreme negative and extreme positive ozone anomalies in, respectively, the first and last deciles of the distribution function of $\mathrm{O}_{3}$ anomalies, calculated with respect to the second-order polynomial fit. Using the method in [29], for extreme $\mathrm{O}_{3}$ anomalies of both signs, we retrieved the fields of transport probability of elementary air masses (air particles) from spatial cells of $1^{\circ} \times 1^{\circ}$ in size toward KHMSS. Figure 6 shows annual average probability of transport of elementary air masses for extremely high and extremely low ozone anomalies at KHMSS.

As can be seen from Fig. 6, regions of the most probable transport of elementary air masses for extreme anomalies of both signs (1) show preferential directions and (2) intersect only in a small region near the station, probably indicating a relationship between extreme ozone concentrations at KHMSS and the horizontal advection of air. Otherwise, such as in the presence of a strong local ozone source or sink, the transport probability spacial distribution would be uniform for extremes of anomalies of both signs. Based 
on Fig. 6, the extremely low ozone concentrations in 2020 can be statistically related to the transport from Krasnodar krai; while the extremely high ozone concentrations can be related to the transport from the regions of Transcaucasia and Turkey across the Main Caucasian Range.

\section{COMPLIANCE WITH HYGIENIC STANDARDS}

Russian Federation authorities established the following hygienic standards for ozone concentration in surface air layer [30, 31]: $0.03 \mathrm{mg} / \mathrm{m}^{3}$, or $30 \mu \mathrm{g} / \mathrm{m}^{3}$ for the daily average maximum permissible concentration $\left(\mathrm{MPC}_{\mathrm{d} . \mathrm{a}}\right) ; 0.16 \mathrm{mg} / \mathrm{m}^{3}$, or $160 \mu \mathrm{g} / \mathrm{m}^{3}$ for the maximum one-time permissible concentration $\left(\mathrm{MPC}_{\mathrm{m.o}}\right)$; and $0.1 \mathrm{mg} / \mathrm{m}^{3}$, or $100 \mu \mathrm{g} / \mathrm{m}^{3}$ for maximum permissible concentration of harmful substance in the air of a work zone $\left(\mathrm{MPC}_{\mathrm{w} . \mathrm{z}}\right)$.

Relying on these standards, we compiled Table 1, which summarizes the cases where the abovementioned MPCs were exceeded.

Data in Table 1 indicate that, according to the national standard, an increase in the background ozone concentration in the surface air layer remained at all these sites in the second half of 2020. Although the excess was observed much less frequently than in the first half-year [15]. The ozone content decreased most strongly at urban stations in Moscow. The excess of 2MPC has also been rare, except at the high-mountain station KHMSS, under the effect of the free troposphere; $50 \%$ of days with a concentration of $2 \mathrm{MPC}_{\text {d.a }}$ are noted in Karadag. Cases with excess of $3 \mathrm{MPC}_{\text {d.a }}$ are

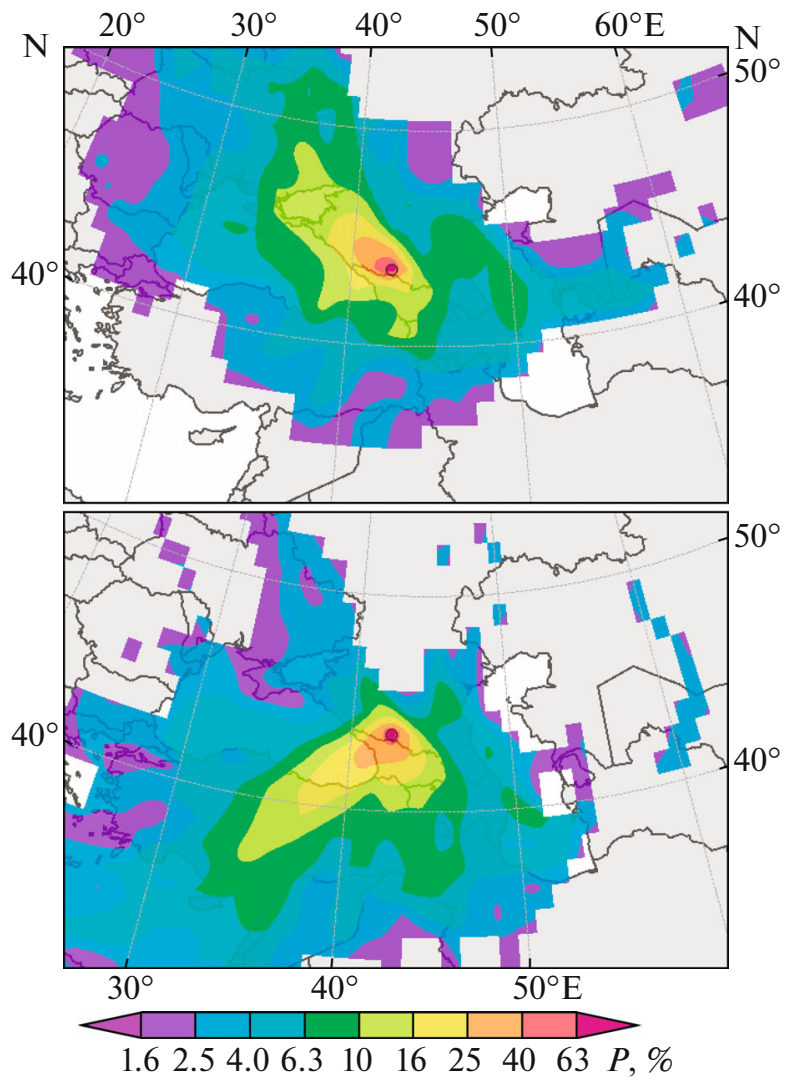

Fig. 6. Probability $(P)$ of passage of elementary air masses, associated with $10 \%$ of the lowest (top panel) and $10 \%$ of the highest (bottom panel) anomalies of surface ozone concentration at KHMSS in 2020, over different territories.

Table 1. Excess over maximum permissible ozone concentrations in the surface air layer on the territory of Russia in the second half of 2020 (days/\%)

\begin{tabular}{|c|c|c|c|c|c|}
\hline \multirow{2}{*}{ Station } & \multicolumn{3}{|c|}{$\operatorname{MPC}_{\text {d.a }}\left(30 \mu \mathrm{g} / \mathrm{m}^{3}\right)$} & \multirow{2}{*}{$\operatorname{MPC}_{\mathrm{w} . \mathrm{z}}\left(100 \mu \mathrm{g} / \mathrm{m}^{3}\right)$} & \multirow{2}{*}{$\mathrm{MPC}_{\mathrm{m} . \mathrm{o}}\left(160 \mu \mathrm{g} / \mathrm{m}^{3}\right)$} \\
\hline & $1 \mathrm{MPC}$ & $2 \mathrm{MPC}$ & $3 \mathrm{MPC}$ & & \\
\hline OPTEC-PR & $67 / 44$ & $10 / 6.5$ & $1 / 0.7$ & 12 & 0 \\
\hline OPTEC-P & $49 / 31$ & $2 / 1.3$ & $0 / 0$ & 3 & 0 \\
\hline SBEM Karadag & $162 / 88$ & $92 / 50$ & $9 / 4.8$ & 27 & 0 \\
\hline Obninsk & $30 / 60$ & $0 / 0$ & $0 / 0$ & 1 & 0 \\
\hline RUDN & $32 / 17$ & $1 / 05$ & $0 / 0$ & 26 & \\
\hline Moscow urban & $30 / 16$ & $0 / 0$ & $0 / 0$ & $0 / 0$ & 1 \\
\hline Moscow roadside & $8 / 4$ & $0 / 0$ & $0 / 0$ & $0 / 0$ & 0 \\
\hline KHMSS & $178 / 100$ & $168 / 94$ & $35 / 20$ & 49 & 0 \\
\hline Vyatskiye Polyany & $118 / 65$ & $15 / 8$ & $0 / 0$ & 13 & 1 \\
\hline TOR station & $150 / 82$ & $18 / 10$ & $2 / 1.1$ & 15 & 0 \\
\hline Fonovaya & $100 / 54$ & $2 / 1.1$ & $0 / 0$ & 0 & 0 \\
\hline Boyarsky & $54 / 100$ & $20 / 37$ & $0 / 0$ & 27 & 0 \\
\hline Apatity & $133 / 75$ & $0 / 0$ & $0 / 0$ & 0 & 0 \\
\hline
\end{tabular}


Table 2. Excess over maximum permissible ozone concentrations in the surface air layer on the territory of Russia per year (days/\%)

\begin{tabular}{l|c|c|c|c|c}
\hline \multirow{2}{*}{\multicolumn{1}{c|}{ Station }} & \multicolumn{3}{|c|}{ MPC $_{\text {d.a }}$} & \multirow{2}{*}{ MPC $_{\mathrm{w} . z}$} & \multirow{2}{*}{$\mathrm{MPC}_{\mathrm{m} . \mathrm{o}}$} \\
\cline { 2 - 5 } & $1 \mathrm{MPC}$ & $2 \mathrm{MPC}$ & $3 \mathrm{MPC}$ & 25 & 2 \\
OPTEC-PR & $201 / 70$ & $116 / 40$ & $26 / 9.1$ & 3 & 0 \\
OPTEC-P & $72 / 21$ & $4 / 1.2$ & $0 / 0$ & 56 & 0 \\
SBEM Karadag & $341 / 93$ & $212 / 58$ & $26 / 7.1$ & 1 & 0 \\
Obninsk & $168 / 77$ & $15 / 7$ & $0 / 0$ & 42 & 1 \\
RUDN & $142 / 42$ & $10 / 2.9$ & $0 / 0$ & 59 & 0 \\
KHMSS & $347 / 100$ & $168 / 96$ & $70 / 20$ & 27 & 1 \\
Vyatskiye Polyany & $118 / 82$ & $82 / 23$ & $0 / 0$ & 60 & 0 \\
TOR station & $331 / 90$ & $59 / 16$ & $18 / 4.9$ & 0 & 0 \\
Fonovaya & $281 / 77$ & $50 / 14$ & $0 / 0$ & & \\
\hline
\end{tabular}

recorded in Tomsk region, St. Petersburg, Karadag, and KHMSS.

Surprisingly, Table 1 shows the quite high frequency of exceeding the MPC in the working zone, in the second half of 2020. Cases with $\mathrm{MPC}_{\mathrm{w} . \mathrm{z}}>100 \mu \mathrm{g} / \mathrm{m}^{3}$ were not recorded at only four out of 13 sites.

In contrast to the first half-year, the maximal onetime MPC in that period of time was exceeded just once at the two sites.

In regard to the observed [32] and forecasted [33] increases in ozone concentration in the surface air layer, serious efforts are required to reduce the emissions of ozone precursor gases, more so considering that positive consequences of reducing their amount do exist in certain regions [34]. It should also be remembered that ozone effects on human health are cumulative when MPCs are simultaneously exceeded for other compounds, and also that it is enhanced during heat waves $[35,36]$.

At nine sites, ozone measurements were carried out throughout the year (Table 2).

Data in Table 2 indicate that $\mathrm{MPC}_{\text {d.a }}$ can be exceeded in all regions where monitoring was performed. If KHMSS is disregarded as a special station, the frequency of occurrence of daily average concentrations of $30 \mu \mathrm{g} / \mathrm{m}^{3}$ and larger is within $21-90 \%$. Concentrations of $60 \mu \mathrm{g} / \mathrm{m}^{3}$ and larger are also observed in all regions, and the frequency of their occurrence varies from 1.2 to $58 \%$. Also, $\mathrm{MPC}_{\mathrm{w} . \mathrm{z}}$ is exceeded in almost all regions. $\mathrm{MPC}_{\mathrm{m} . \mathrm{o}}$ is exceeded in five regions.

\section{CONCLUSIONS}

Our review shows the ozone concentration in the surface air layer to exceed the national hygienic stan- dards in most sites on the territory of Russia in the second half of 2020. This requires a more comprehensive analysis of ozone-forming substances and a development of measures to reduce their supply to the atmosphere.

It is also obvious that the data presented in the review are mosaic: there are no data for many large regions of the country. This indicates that the ozone monitoring sites should be increased in number.

\section{ACKNOWLEDGMENTS}

The authors would like to thank the Department of Nature Management and Environmental Protection of Moscow and personally E.G. Semutnikova for creation of the monitoring system, comparable with the foreign analogs, for its development and maintenance at the modern level. The authors would also like to thank the State Atomic Energy Corporation Rosatom for support in creating the station in RUDN.

The review was prepared using data obtained using the infrastructure of the Institute of Atmospheric Optics, Siberian Branch, Russian Academy of Sciences, including the Center for Collective Use Atmosfera; of the Institute of Physical Material Science, Siberian Branch, Russian Academy of Sciences; of Karadag Scientific Station-Nature Reserve of Russian Academy of Sciences, O.A. Kovalevsky Institute of Biology of the Southern Seas, Russian Academy of Sciences; and of the Institute of Atmospheric Physics, Russian Academy of Sciences, all created and operated in the framework of state orders.

\section{CONFLICT OF INTEREST}

The authors declare that they have no conflicts of interest. 


\section{REFERENCES}

1. P. Voosen, "Global temperatures in 2020 tied record highs," Science 371 (6527), 334-335 (2021).

2. "Delaying COP26 is not a reason to delay climate action," Nature 582 (7810), 7 (2020).

3. D. Rosenbloom and J. Markard, "A COVID-19 recovery for climate," Science 371 (6490), 447-448 (2020).

4. "News from a postpandemic world," Science 369 (6499), 26-29 (2020).

5. S. Jain and T. Sharma, "Social and travel lockdown impact considering coronavirus disease (COVID-19) on air quality in megacities of India: Present benefits, future challenges and way forward," Aerosol. Air Qual. Res. 20 (6), 1222-1236 (2020).

6. I. Salma, M. Vorosmarty, A. Z. Gyongyosi, W. Then, and T. Weidinger, "What can we learn about urban air quality with regard to the first outbreak of the COVID-19 pandemic? A case study from central Europe," Atmos. Chem. Phys. 20 (24), 15725-15742 (2020).

7. A. S. Ginzburg, V. A. Semenov, E. G. Semutnikova, M. A. Aleshina, P. V. Zakharova, and E. A. Lezina, "Impact of COVID-19 lockdown on air quality in Moscow," Dokl. Earth Sci. 495 (1), 862-866 (2020).

8. L. Wang, J. Wang, and Ch. Fang, "Assessing the impact of lockdown on atmospheric ozone pollution amid the first half of 2020 in Shenyang, China," Int. J. Environ. Res. 17 (23), 9004 (2020).

9. J. D. Lee, W. S. Drysdale, D. P. Finch, S. E. Wilde, and P. I. Palmer, "UK surface $\mathrm{NO}_{2}$ levels dropped by $42 \%$ during the COVID-19 lockdown: Impact on surface $\mathrm{O}_{3}$," Atmos. Chem. Phys. 20 (24), 15743-15759 (2020).

10. P. Sicard, A. De Marco, E. Agathokleous, Z. Feng, X. Xu, E. Paoletti, J. J. D. Rodriguez, and V. Calatayud, "Amplified ozone pollution in cities during the COVID-19 lockdown," Sci. Total Environ. 735, 139542 (2020).

11. K. B. Moiseenko, E. V. Berezina, A. V. Vasil'eva, Yu. A. Shtabkin, A. I. Skorokhod, N. F. Elanskii, and I. B. Belikov, "The $\mathrm{NO}_{\mathrm{x}}$-limiting regime of photochemical ozone generation in a weakly polluted convective boundary layer: Observations at the ZOTTO tall tower observatory in central Siberia, 2007-2015," Dokl. Earth Sci. 487 (2), 981-985 (2019).

12. K. Xu, K. Cui, L.-H. Young, Y.-K. Hsieh, Y.-F. Wang, J. Zhang, and S. Wan, "Impact of the COVID-19 event on air quality in central China," Aerosol. Air Qual. Res. 20 (5), 915-929 (2020).

13. M. Yao, L. Zhang, J. Ma, and L. Zhou, "On airborne transmission and control of SARS-Cov-2," Sci. Total Environ. 731, 139178 (2020).

14. Q. Schiermeier, "Why pollution is falling in some cities-but not others," Nature 580 (7803), 313 (2020).

15. V. V. Andreev, M. Yu. Arshinov, B. D. Belan, D. K. Davydov, N. F. Elansky, G. S. Zhamsueva, A. S. Zayakhanov, G. A. Ivlev, A. V. Kozlov, S. N. Kotel'nikov, I. N. Kuznetsova, V. A. Lapchenko, E. A. Lezina, O. V. Postylyakov, D. E. Savkin, I. A. Senik, E. V. Stepanov, G. N. Tolmachev, A. V. Fofonov, I. V. Chelibanov, V. P. Chelibanov, and V. V. Shirotov, "Surface ozone concentration over Russian territory in the first half of 2020," Atmos. Ocean. Opt. 33 (6), 671681 (2020).

16. A. M. Zvyagintsev and I. N. Kuznetsova, "Surface ozone variations in Moscow environs: The results of continuous ten-year observations," Izv. Atm. Ocean. Phys. 38 (4), 431-439 (2002).

17. G. Vigliono, "COVID-19 could ruin weather forecasts and climate records," Nature 580 (7804), 440-441 (2020).

18. https://mosecom.mos.ru. Cited January 25, 2021.

19. https://mosecom.mos.ru/vozdux/. Cited January 25, 2021.

20. V. A. Lapchenko and A. M. Zvyagintsev, "Trace atmospheric gases in the Karadag nature reserve in Crimea," Atmos. Ocean. Opt. 28 (4), 308-311 (2015).

21. U. Niinements, "What are plant-released biogenic volatiles and how they participate in landscape- to globallevel processes?," in Ecosystem Services from Forest Landscapes (Springer, 2018), 29-56.

22. T. Miyama, T. Morishita, Y. Kominami, H. Noguchi, Y. Yasuda, N. Yoshifuji, M. Okano, K. Yamanoi, Y. Mizoguchi, S. Takanashi, K. Kitamura, and K. Matsumoto, "Increases in biogenic volatile organic compound concentrations observed after rains at six forest sites in non-summer periods," Atmosphere 11 (2020). https://doi.org/10.3390/atmos11121381

23. I. A. Senik, N. F. Elanskii, I. B. Belikov, L. V. Lisitsyna, V. V. Galaktionov, and Z. V. Kortunova, "Main patterns of the temporal variability of surface ozone in the region of the town of Kislovodsk at 870 and $2070 \mathrm{~m}$ above sea level," Izv. Atm. Ocean. Phys. 41 (1), 67-79 (2005).

24. R. R. Draxler and G. D. Hess, "An overview of the HYSPLIT 4 modeling system of trajectories, dispersion, and deposition,” Aust. Meteor. Mag. 47, 295-308 (1998).

25. http://ready.arl.noaa.gov/HYSPLIT.php. Cited January 25, 2021.

26. E. Kalnay, M. Kanamitsu, R. Kistler, W. Collins, D. Deaven, L. Gandin, M. Iredell, S. Saha, G. White, J. Woolen, Y. Zhu, A. Leetmaa, and R. Reynolds, "The NCEP/NCAR 40-year reanalysis project," Bull. Am. Meteorol. Soc. 77, 437-471 (1996).

27. R. Kistler, E. Kalnay, W. Collins, S. Saha, G. White, J. Woolen, M. Chelliah, W. Ebisuzaki, M. Kanamitsu, V. Kousky, H. Dool, R. Jenne, and M. Fiorino, "The NCEP/NCAR 50-year reanalysis: Monthly means CD-ROM and documentation," Bull. Am. Meteorol. Soc. 82, 247-268 (2001).

28. K. A. Shukurov and O. G. Chkhetiani, "Probability of transport of air parcels from the arid lands in the Southern Russia to Moscow region," Proc. SPIE 10466 (2017). https://doi.org/10.1117/12.2287932

29. Hygienic Standard GN 2.1.6.3492-17 "Maximum Allowable Concentration (MAC) of Harmful Substances in the Urban and Rural Atmospheric Air". Order of the Russia's Chief Public Health Officer no. 165 of December 22, 2017 (amended on May 31, 2018).

30. Hygienic Standard GN 2.2.5.3532-18 "Maximum Allowable Concentration (MAC) of Harmful Substances 
in the Working Zone Area." Order of the Russia's Chief Public Health Officer no. 25 of February 13, 2018.

31. X. Ma, J. Huang, T. Zhao, Ch. Liu, K. Zhao, J. Xing, and W. Xiao, "Rapid increase in summer surface ozone over the north China plain during 2013-2019: A side effect of particulate matter reduction control?," Atmos. Chem. Phys. 21 (1), 1-16 (2021).

32. D. J. Rasmussen, J. Hu, A. Mahmud, and M. J. Kleeman, "The Ozone-climate penalty: Past, present, and future," Environ. Sci. Technol. 47 (11), 14258-14266 (2013).

33. Y. Zhang, J. J. West, L. K. Emmons, J. Flemming, J. E. Jonson, M. T. Lund, T. Sekiya, K. Sudo, A. Gaudel, K.-L. Chang, Ph. Nedelec, and V. Thouret, "Contributions of world regions to the global tropospheric ozone burden change from 1980 to 2010," Geophys. Rev. Lett. 48 (1) (2021).

34. M. S. Hossain, Frey Ch. Christopher, P. K. K. Louie, and A. K. H. Lau, "Combined effects of increased $\mathrm{O}_{3}$ and reduced $\mathrm{NO}_{2}$ concentrations on short-term air pollution health risks in Hong Kong," Environ. Pollut. 270, 116280 (2021).

35. E. Hertig, A. Russo, and R. M. Trigo, "Heat and ozone pollution waves in central and south Europe-characteristics, weather types, and association with mortality," Atmosphere 11 (123) (2020).

https://doi.org/10.3390/atmos11121271

Translated by $O$. Bazhenov 